\title{
DESIGNING LEARNING TRAJECTORY OF SET THROUGH THE INDONESIAN SHADOW PUPPETS AND MAHABHARATA STORIES
}

\author{
Irma Risdiyanti, Rully Charitas Indra Prahmana* \\ Universitas Ahmad Dahlan, Indonesia
}

\begin{tabular}{l} 
Article Info \\
\hline Article history: \\
Received June 28, 2021 \\
Revised July 28, 2021 \\
Accepted July 30, 2021 \\
\hline
\end{tabular}

\section{Keywords:}

Design Research, Ethnomathematics, Indonesian Shadow Puppets, Mahabharata Stories, Realistic Mathematics Education, Set

\begin{abstract}
Indonesia has many cultures that can be used as a starting point in learning mathematics. Yet, many teachers still use conventional methods to provide explicit mathematical content without connecting with students' culture and daily activities. One of the learning approaches that can solve these problems is Realistic Mathematics Education (RME). This approach uses context as one of its characteristics containing students' culture and their daily activities. On the other hand, Wayang (Indonesian shadow puppets) and Mahabharata stories have the characteristics that can be a context in the learning of set. This research aims to design the Hypothetical Learning Trajectory (HLT) of the set using the RME approach through Wayang and Mahabharata stories, which are familiar with students' culture in Yogyakarta. This HLT will then be tested on students in further research until it becomes the Local Instructional Theory (LIT) on set. Students can study about set by grouping Wayang in Mahabharata stories based on their characters. The research result is the HLT of set through the context of wayang and Mahabharata stories containing learning goals, learning activities, and the conjecture of every activity. This HLT can be a promising solution to overcome students' difficulties in understanding the concept of sets and values in the cultural context to improve the students' character.
\end{abstract}

Copyright (C) 2021 IKIP Siliwangi. All rights reserved.

\section{Corresponding Author:}

Rully Charitas Indra Prahmana,

Departement of Mathematics Education,

Universitas Ahmad Dahlan

Jl. Pramuka No. 42, Pandeyan, Umbulharjo, Yogyakarta 55161, Indonesia

Email: rully.indra@mpmat.uad.ac.id

\section{How to Cite:}

Risdiyanti, I., \& Prahmana, R. C. I. (2021). Designing learning trajectory of set through the Indonesian shadow puppets and Mahabharata stories. Infinity, 10(2), 331-348.

\section{INTRODUCTION}

In principle, the elements that build mathematical concepts come from several things developed by humans to respond to the surrounding environment, such as seeking explanations, understanding, experiences, and solutions to phenomena or events around them that they experience (Ernest et al., 2016; Freudenthal, 2006; D'Ambrosio, 2007). In addition, mathematics cannot construct itself. Still, it is influenced by historical, environmental, social, and geographical aspects or what we call a culture where humans develop and process their lives (Risdiyanti \& Prahmana, 2017; Utami, Sayuti, \& Jailani, 2019). As a result, it becomes inflexible and becomes far from culture and everyday life, 
where humans develop and process it (Alangui, 2010; Muhtadi et al., 2017). Therefore, mathematics is very close and departs from culture and daily human life, eventually becoming a proper formal education or school form.

The mathematics learning problem is inseparable from the efforts of the West to try to hegemony science to dull the thinking ability of individuals who study mathematics so that it can facilitate and perpetuate colonialism and western influence on other civilizations (D'Ambrosio, 2007; Joseph, 2010). The mathematics form is rigid and far from the origin of the construction of mathematical concepts (Risdiyanti \& Prahmana, 2020a). It's causing mathematics learning to be limited to knowledge transfer. Students only accept it without critical and reflective thinking on the knowledge and cannot know its meaning and use in everyday life (D'Ambrosio, 2016). Thus, a learning approach that is close to culture and human activities is needed to solve these problems in learning mathematics.

D'Ambrosio (1985), a mathematician from Brazil, initiated the Ethnomathematics approach as a solution. Ethnomathematics is a way to study and combine ideas, methods, and techniques used and developed by socio-cultural or members of different cultures to learn mathematical concepts (D'Ambrosio, 2016; Rosa \& Orey, 2016). It is reflecting on how mathematics was developed based on how mathematics is taught in schools. Ethnomathematics tries to reconstruct mathematics so that it is rooted in different cultures and accommodates other ideas so that students become able to reason critically, democratically and can be tolerant of various ideas and ideas during teaching and learning activities (D'Ambrosio, 2016; Risdiyanti \& Prahmana, 2020a). Therefore, ethnomathematics can be used as one of the educational innovations in mathematics learning, aiming to make students love mathematics, be motivated, and increase creativity in mathematics through their culture.

Indonesia is a country with an abundant culture to instill mathematical ideas, methods, and techniques through mathematical modeling (Prahmana et al., 2021). This approach creates opportunities in mathematics learning to use local contexts or cultures that can increase students' critical reasoning and interest by rediscovering mathematics rooted in the culture around students and benefiting from the mathematical concepts it finds. One of the cultures in Java, especially in Central Java, East Java, and the Special Region of Yogyakarta, which has mathematical characteristics, is Wayang. Elements of wayang characters known by the Javanese people have several similarities to identify kind, evil, caste, and several things in them. In addition, there are still many Javanese people who hold Wayang performances at certain events. Mathematical modeling in the context of wayang characters and their stories is expected to teach mathematics. Learning mathematics using the cultural context used in learning mathematics has been documented by some researchers, i.e., the Gadang Minangkabau house for learning the Pythagorean theorem (Rahmawati, 2020), the Soko Tunggal mosque for learning two-dimensional geometry (Putra, Wijayanto, \& Widodo, 2020), Megono Gunungan for learning cones (Nursyahidah et al., 2020), Batik cloth motifs for learning reflection (Novrika, Putri, \& Hartono, 2016), and Bamboo craft for learning translational (Maryati \& Prahmana, 2020).

Ethnomathematics is mathematics that exists from how society uses mathematics to deal with their everyday life (D'Ambrosio, 2007). Ethnomathematics can be part of the Realistic Mathematics Education approach, mainly an authentic context used as a starting point in the learning process (Risdiyanti \& Prahmana, 2020a). Therefore, students can understand a mathematical concept from the culture, which implicitly contains mathematical concepts.

Realistic Mathematics Education approach with characteristics of using real context as a starting point in learning can be a place for Ethnomathematics, an authentic context in learning mathematics. Real contexts in RME aim to make it easier for students to understand 
and abstract the mathematical concepts learned from non-formal to formal forms (Hadi, 2017; Soedjadi, 2007). In this approach, the teacher acts as a facilitator who accompanies the emergence of students' thinking strategies and not as a source that indoctrinates students' thinking (Hadi, 2017). In this approach, students are more likely to be given the freedom to think critically, be independent, and find the knowledge and mathematical concepts they want to know and learn (Meirisa, Rifandi, \& Masniladevi, 2018; Hadi, 2017). Through RME, which uses real contexts such as culture and everyday life, students create a pragmatic view of society, and students who view mathematics as a scary and challenging science to learn and far from civilization and everyday life can be minimized (Risdiyanti, Prahmana, \& Shahrill, 2019; Zulkardi, Putri, \& Wijaya, 2020). In addition, with the actual context used in RME, students can critically take the meaning of the mathematics they are learning and can feel the benefits to solve the problems they face in students' daily lives (Hadi, 2017; Risdiyanti \& Prahmana, 2020a).

Several researchers have documented the students' difficulty in understanding the concept of set, applying the principles, understanding questions, transforming questions, solving problems, including related story questions with students' daily lives (Dwidarti, Mampouw, \& Setyadi, 2019; Ratnasari \& Setiawan, 2019). At the same time, the concept of a set is a fundamental concept used to understand other materials such as relations and functions (Nurtasari, Jamiah, \& Suratman, 2017). If students have difficulty understanding the idea of a set, it won't be easy to understand other related materials. Therefore, it is very urgent to design learning that can be used to understand and make it easier for students to understand this concept.

This study aims to design a learning trajectory of set learning using the RME approach and the Mahabharata Puppet and Storie's context. The use of wayang context is because there are several characterizations in the wayang story, namely protagonist, antagonist, and the tritagonist. The wayang characters are depicted in the visuals of the wayang faces to be easily identified as evil puppets and good puppets. Concerning the set concept, several characters in the Mahabharata story can be seen based on the storyline's learning nature and the method's visualization. This can be used as a starting point in understanding and rediscovering the concept of sets. In addition, wayang is also a culture that contains moral values and a philosophy of life. This is very useful for students to emulate simultaneously for the good character in students (Kasim, 2018).

As a result, a learning trajectory based on a realistic mathematics education approach is required to facilitate students' understanding of sets. Students will study mathematics to solve problems encountered in their daily lives. This learning trajectory is in the form of learning steps that begin with introducing the actual context, then use that context to rediscover mathematical concepts until finally, students can understand the concept in a standard form. Additionally, this outcome will comprehend the relationship between mathematics, culture, and students' daily lives, be familiar with mathematics' applications and encourage students to think critically and meaningfully. This learning trajectory may be an alternative solution for increasing student understanding of the set and preserving Indonesian culture.

\section{METHOD}

In this study, the researchers designed the alleged set learning trajectory using a Realistic Mathematics Education approach with the context of Wayang and Mahabharata Story. This design is done by analyzing the culture that students are familiar with and then compiling a mathematical abstraction process that can be done using the real context that 
exists around the students. Next, the researcher arranges the learning steps along with the conjecture or conjecture of the student's response and the alleged response that the teacher must give to anticipate the answer given by the student. This study is part of design research. The research design is to develop an intervention in teaching and learning activities as a solution to solve educational problems (Plomp, 2013; Gravemeijer \& Cobb, 2006). The design research method can answer the problem formulation and achieve the research objectives (Prahmana, 2017; Plomp, 2013). This method allows researchers to study student learning processes. In addition, knowing to what extent the activities that have been designed can support students' understanding of the circle material.

This research is the first phase of design research, namely the preliminary design or research. In the initial design stage, researchers prepare to learn activities through literature review. Researchers obtained information about students' difficulties in learning circles and what activities can support students' understanding of sets from the literature. Before the learning trajectory becomes a local instructional theory, the steps are formulated in advance in the form of alleged learning steps and the alleged responses of students and teachers called the Hypothetical Learning Trajectory.

\section{RESULTS AND DISCUSSION}

\subsection{Results}

In this study, the researcher implemented the initial idea of using the context of wayang and Mahabharata stories in group learning by reviewing the literature. After that, the researcher made observations to the Muhammadiyah Magelang Elementary School regarding the context used and ended by designing a Hypothetical Learning Trajectory (HLT). The development of HLT in every learning activity is an essential part of designing student learning activities. The design of learning activities is inseparable from the learning trajectory, which contains a hypothesis plan for learning materials, where the learning trajectory is a concept trajectory that students will pass during the learning process. Furthermore, the learning trajectory, the learning activities, and the context used in the learning of set will become a local instructional theory in the learning process that has been designed (see Figure 1).

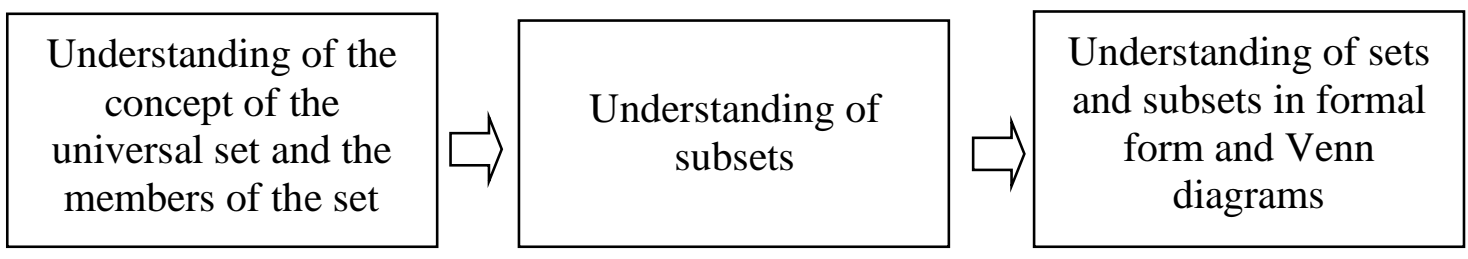

Figure 1. Learning trajectory for set learning

Several activities have been designed based on the hypothesized learning trajectory and students' thought processes. This set of instructional activities has been divided into three activities which were completed in 3 meetings. This research is intended to understand one or more basic concepts of sets in everyday life activities. The relationship between student learning paths, learning activities, and the basic concepts of the set can be seen in Table 1 . 
Table 1. The relationship between student learning paths, learning activities, and the basic concepts

\begin{tabular}{|c|c|c|c|}
\hline & $\begin{array}{c}\text { Student } \\
\text { Learning Paths }\end{array}$ & Learning Activities & $\begin{array}{l}\text { Set Basic } \\
\text { Concepts }\end{array}$ \\
\hline \multirow{3}{*}{$\begin{array}{l}\text { Activity } \\
\text { base on } \\
\text { experience } \\
\text { (Mode of) }\end{array}$} & Activity 1 & Watching the Mahabarata Wayang & \multirow[t]{3}{*}{ Universal Set } \\
\hline & Watching the & Stories by Ki Seno & \\
\hline & $\begin{array}{l}\text { Mahabarata } \\
\text { Wayang Stories } \\
\text { by Ki Seno }\end{array}$ & $\begin{array}{l}\text { Identify the characters of Wayang } \\
\text { Mahabarata }\end{array}$ & \\
\hline
\end{tabular}

\begin{tabular}{|c|c|c|c|}
\hline $\begin{array}{l}\text { Laison } \\
\text { Activities } \\
\text { (Mode for) }\end{array}$ & $\begin{array}{l}\text { Activity } 2 \\
\text { Help Ki Seno to } \\
\text { compose the } \\
\text { Mahabarata } \\
\text { Wayang on Kelir } \\
\text { Screen }\end{array}$ & $\begin{array}{l}\text { Understanding the pattern of } \\
\text { arrangement of the wayang } \\
\text { mahabarata on the kelir screen } \\
\text { Understanding the difference wayang } \\
\text { between of evil and kind characters } \\
\text { seen from the seen of the face } \\
\text { Classifying wayang based on evil } \\
\text { characters } \\
\text { Classifiying wayang based on kind } \\
\text { characters } \\
\text { Clasifiying wayang based on } \\
\text { pandhawa lima group } \\
\text { Clasifiying wayang based on kurawa } \\
\text { group }\end{array}$ & Subset \\
\hline $\begin{array}{l}\text { Formal } \\
\text { Knowledge }\end{array}$ & $\begin{array}{l}\text { Activity } 3 \\
\text { Write the Set of } \\
\text { Mahabarata } \\
\text { Wayang }\end{array}$ & $\begin{array}{l}\text { Define the set } \\
\text { Define the member of set } \\
\text { Write the set-in formal form } \\
\text { Define the subset } \\
\text { Write the subset in formal from } \\
\text { Determine subsets and draw them in } \\
\text { the form of a venn diagram } \\
\text { Write the experience of learning }\end{array}$ & $\begin{array}{l}\text { Definition } \\
\text { and formal } \\
\text { form of sets, } \\
\text { members of } \\
\text { sets and } \\
\text { subsets }\end{array}$ \\
\hline
\end{tabular}

A set of learning activities as contained in the Hypothetical Learning Trajectory (HLT) in Table 1 consists of 4 activities. The details can be explained as follows.

\subsubsection{Activity 1: Watching the Mahabharata Wayang Show by Ki Seno}

In this first activity, students watched the Mahabharata wayang show masterminded by Ki Seno. Next, students identify the wayang characters in the Mahabharata story. In this activity, the teacher starts the lesson by distributing student books to the students. Then ask 
students about their knowledge and experience about wayang and the Mahabharata story, then ask students to explain what they know or explain their experience. The teacher then asked the students to read the information about the wayang and the Mahabharata story in the student book. Next, the teacher asks students to follow the learning steps in the student book. The teacher asks students to play of a wayang animation video with the Mahabharata story in the student book. The duration of video is 3 minutes. Then, the teacher asks students to identify the wayang characters in the Mahabharata story and write their names in the column provided in the student book. Finally, students are asked to present their work in front of the class for discussion.

\section{Purpose of Activity 1}

This first activity aims to find out the students' knowledge and experience regarding the context of the wayang and the Mahabharata story. In addition, to identify the wayang characters in the Mahabharata story, which is actually a clearly defined object, namely the wayang object in the Mabaharata story, with the hope that a 'student language' will appear for the set, namely a collection of objects that have clearly defined properties. As well as appearing 'student language' for members of the set, namely objects or objects that are clearly defined.

\section{Student Book and Conjecture of Activity 1}

In this first activity, students are guided by the teacher by using a student book. Student activity begins with getting to know wayang and the Mahabharata story. Then, the students watched the wayang show with the Mahabharata story. After that, students write down the Mahabharata wayang figures in the columns provided in the student books. More details can be seen in Figure 2.

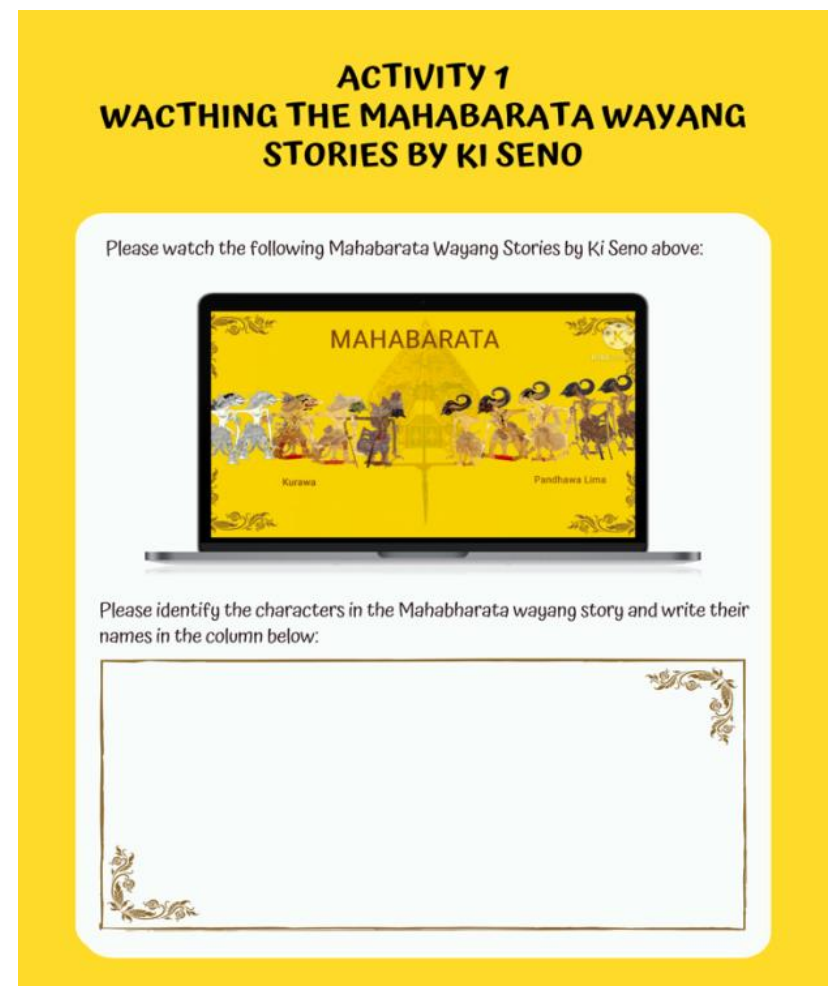

Figure 2. Activity 1 in the student book 
The conjecture in the first activity consists of activities, predictions of student responses, and the teacher's responses in response to the responses given by these students. More details can be seen in Table 2.

Table 2. Conjecture of activity 1

\begin{tabular}{|c|c|c|c|}
\hline No & Activity & $\begin{array}{c}\text { Predictions of student } \\
\text { responses }\end{array}$ & Teacher's Responses \\
\hline \multirow[t]{2}{*}{1} & \multirow{2}{*}{$\begin{array}{l}\text { The teacher asks } \\
\text { students about their } \\
\text { knowledge and } \\
\text { experience about } \\
\text { wayang and the } \\
\text { Mahabharata story. }\end{array}$} & $\begin{array}{l}\text { Know and/or have } \\
\text { experience about wayang } \\
\text { and Mahabharata stories }\end{array}$ & $\begin{array}{l}\text { The teacher asks students to share their } \\
\text { knowledge and experiences about } \\
\text { wayang and the Mahabharata story. }\end{array}$ \\
\hline & & $\begin{array}{l}\text { Don't know and/or don't } \\
\text { have experience with } \\
\text { wayang and Mahabharata } \\
\text { stories cerita }\end{array}$ & $\begin{array}{l}\text { The teacher tells about the wayang and } \\
\text { the Mahabharata story, then asks the } \\
\text { students to read the information about } \\
\text { the Mahabharata wayang and story in } \\
\text { the student book. }\end{array}$ \\
\hline \multirow[t]{2}{*}{2} & \multirow[t]{2}{*}{$\begin{array}{l}\text { Students write the } \\
\text { Mahabharata } \\
\text { wayang character }\end{array}$} & $\begin{array}{l}\text { Write all the wayang } \\
\text { characters in the } \\
\text { Mahabharata story }\end{array}$ & $\begin{array}{l}\text { The teacher gives a verbal appreciation } \\
\text { of the student's work. }\end{array}$ \\
\hline & & $\begin{array}{l}\text { Writing some of the } \\
\text { wayang characters in the } \\
\text { Mahabharata story }\end{array}$ & $\begin{array}{l}\text { The teacher guides the students to be } \\
\text { able to write down all the Mahabharata } \\
\text { wayang characters. }\end{array}$ \\
\hline
\end{tabular}

\subsubsection{Activity 2: Compose the Mahabharata Wayang on the Kelir Screen}

In this second activity, students arrange wayang characters in the Mahabharata story in wayang colors. The steps for compiling the wayang characters in the Mahabharata story on screen are from the wayang characters that have been identified in the previous activity and have been written in the student's book. Then the wayang characters are separated based on kind and evil characters and based on the groups of wayang pandhawa five and wayang kurawa. Then students arrange the wayangs on the wayang screen with the arrangement pattern as determined in the student book. Finally, students are asked to present their work in front of the class for discussion.

\section{Purpose of Activity 2}

The purpose of this second activity is to encourage students to understand and identify wayang characters who have kind and evil characters, as well as five wayang characters and wayang kurawa characters, which are actually a subset of a universal set of Mahabharata wayang figures. The hope is that a 'student language' will appear for subsets, namely sets whose members are included in other sets. And students can write sets and subsets in formal form and Venn diagrams.

\section{Student Book and Conjecture of Activity 2}

In this second activity, students are guided by the teacher using student books. This second activity begins with students observing and understanding the pattern of wayang arrangement on the wayang screen. Then the students grouped the Mahabharata wayangs based on their character as seen from their face shape. The students then grouped the kind wayangs and the evil wayangs and the five pandhawa wayangs and the kurawa wayangs. 
After that, students arrange the names of the wayangs on the color of the wayangs. More details can be seen in Figure 3 and Figure 4.
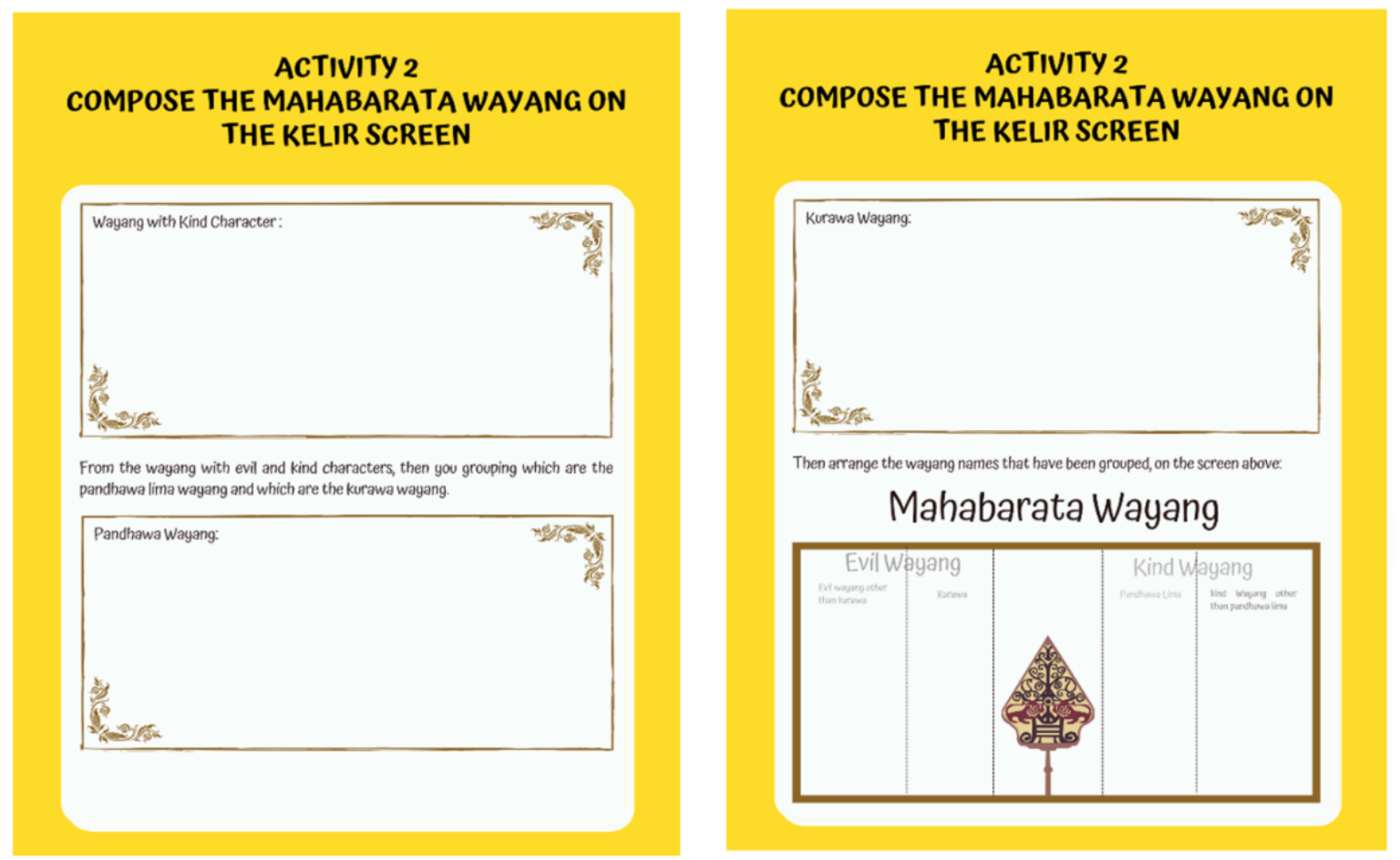

Figure 3. Student understanding the pattern of Kelir Wayang and the character wayang base on the fase shape
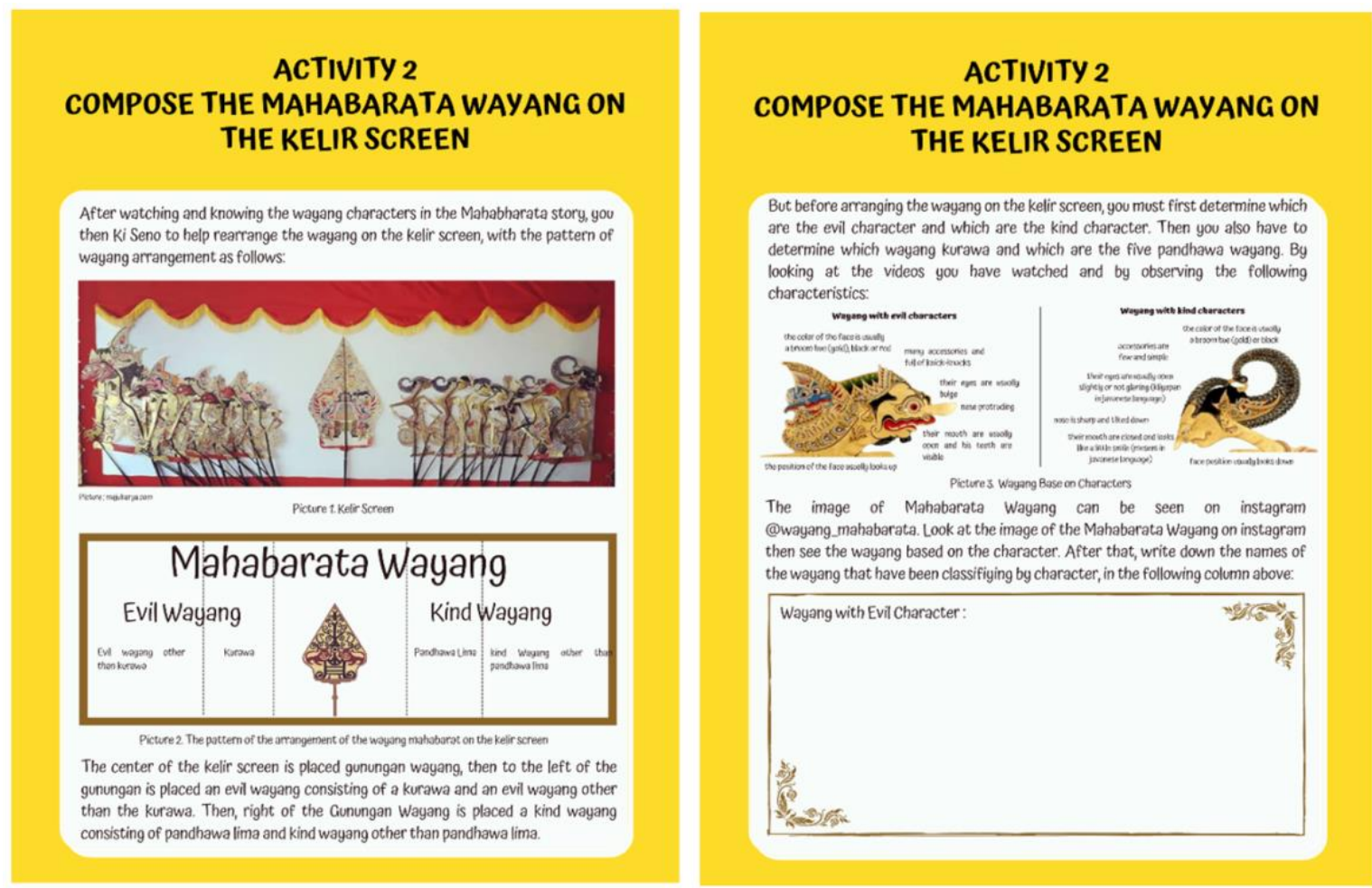

Figure 4. Student classifying Mahabharata Wayang and compose Wayang in Kelir Screen 
The conjecture in the second activity consists of activities, predictions of student responses, and the responses that the teacher must give in response to the responses given by these students. More details can be seen in Table 3.

Table 3. Conjecture of activity 2

\begin{tabular}{|c|c|c|c|}
\hline No & Activity & $\begin{array}{c}\text { Predictions } \\
\text { of student responses }\end{array}$ & Teacher's Responses \\
\hline 1 & $\begin{array}{l}\text { Students } \\
\text { observe and } \\
\text { understand the } \\
\text { pattern of the } \\
\text { arrangement of } \\
\text { the wayangs on } \\
\text { the kelir screen }\end{array}$ & $\begin{array}{l}\text { Students understand the pattern } \\
\text { of the arrangement of the } \\
\text { wayangs on the screen } \\
\text { Students do not understand the } \\
\text { pattern of wayang arrangement } \\
\text { on the screen }\end{array}$ & $\begin{array}{l}\text { The teacher gives a verbal } \\
\text { appreciation for students } \\
\text { The teacher helps students to be able } \\
\text { to understand the pattern of the } \\
\text { arrangement of the wayangs on the } \\
\text { screen }\end{array}$ \\
\hline 2 & $\begin{array}{l}\text { Students } \\
\text { observe the } \\
\text { differences in } \\
\text { the character of } \\
\text { the wayang } \\
\text { based on the } \\
\text { shape of the } \\
\text { face }\end{array}$ & $\begin{array}{l}\text { Students understand the } \\
\text { differences in wayang } \\
\text { characters based on face shape } \\
\text { Students do not understand the } \\
\text { differences in the character of } \\
\text { the wayang based on the shape } \\
\text { of the face }\end{array}$ & $\begin{array}{l}\text { The teacher gives a verbal } \\
\text { appreciation for students } \\
\text { The teacher helps students to be able } \\
\text { to understand the differences in the } \\
\text { character of the wayang based on } \\
\text { the shape of the face by looking at } \\
\text { the different parts of the faces of the } \\
\text { evil and kind wayangs }\end{array}$ \\
\hline 3 & $\begin{array}{l}\text { Students write } \\
\text { the names of the } \\
\text { evil wayang } \\
\text { characters }\end{array}$ & $\begin{array}{l}\text { Students can write down the } \\
\text { names of all the evil characters } \\
\text { of Mahabharata wayangs } \\
\text { Students have not been able to } \\
\text { write the names of all the } \\
\text { Mahabharata wayangs with } \\
\text { kind character }\end{array}$ & $\begin{array}{l}\text { The teacher gives a verbal } \\
\text { appreciation for students } \\
\text { The teacher helps students to be able } \\
\text { to identify the evil wayang by } \\
\text { looking at the characteristics of its } \\
\text { face and also the characters in the } \\
\text { Mahabharata wayang storyline in } \\
\text { the video that has been played. }\end{array}$ \\
\hline 4 & $\begin{array}{l}\text { Students write } \\
\text { the names of the } \\
\text { five pandhawa } \\
\text { wayang } \\
\text { characters }\end{array}$ & $\begin{array}{l}\text { Students can write the names of } \\
\text { the five pandhawa wayangs } \\
\text { Students have not been able to } \\
\text { write the names of all the five } \\
\text { pandhawa wayangs }\end{array}$ & $\begin{array}{l}\text { The teacher gives a verbal } \\
\text { appreciation for students } \\
\text { The teacher helps students to be able } \\
\text { to identify the pandhawa wayang } \\
\text { from the Mahabharata wayang } \\
\text { storyline on the video that has been } \\
\text { played }\end{array}$ \\
\hline 5 & $\begin{array}{l}\text { Students write } \\
\text { down the names } \\
\text { of the Kurawa } \\
\text { wayang } \\
\text { characters }\end{array}$ & $\begin{array}{l}\text { Students can write wayang } \\
\text { kurawa } \\
\text { Students have not been able to } \\
\text { write the names of all the } \\
\text { Kurawa wayangs }\end{array}$ & $\begin{array}{l}\text { The teacher gives a verbal } \\
\text { appreciation for students } \\
\text { The teacher helps students to be able } \\
\text { to identify the wayang kurawa from } \\
\text { the storyline of the Mahabharata } \\
\text { wayang on the video that has been } \\
\text { played }\end{array}$ \\
\hline
\end{tabular}




\subsubsection{Activity 3: Writing the Set of Mahabharata Wayang}

In this activity, students write sets in formal form, including the universal set of wayang characters in the Mabaharata story, subsets, namely the set of kind Mahabharata wayang figures, the evil Mahabharata wayang figures, the five pandhawa wayang figures, the Kurawa wayang figures that have been compiled in wayang color. Students write these sets in the set column in the student book. Finally, students are asked to present their work in front of the class for discussion.

\section{Purpose of Activity 3}

This third activity aims to encourage students' understanding in writing or representing sets in a formal form. The hope is that students can represent the universal set and subsets in a formal form.

\section{Student Book and Conjecture of Activity 3}

Activity 3 in the student book begins with students defining sets when it is known that the results of grouping wayang characters in the Mahabharata story are called sets. Furthermore, students are given examples of writing sets in formal form, then students write down the results of grouping wayang or wayang sets in formal form. After that, it is known that the five pandhawa wayang sets consisting of yudihistira, bima, arjuna, nakula and sadewa are then called members of the set, students then define the members of the set using students' language.

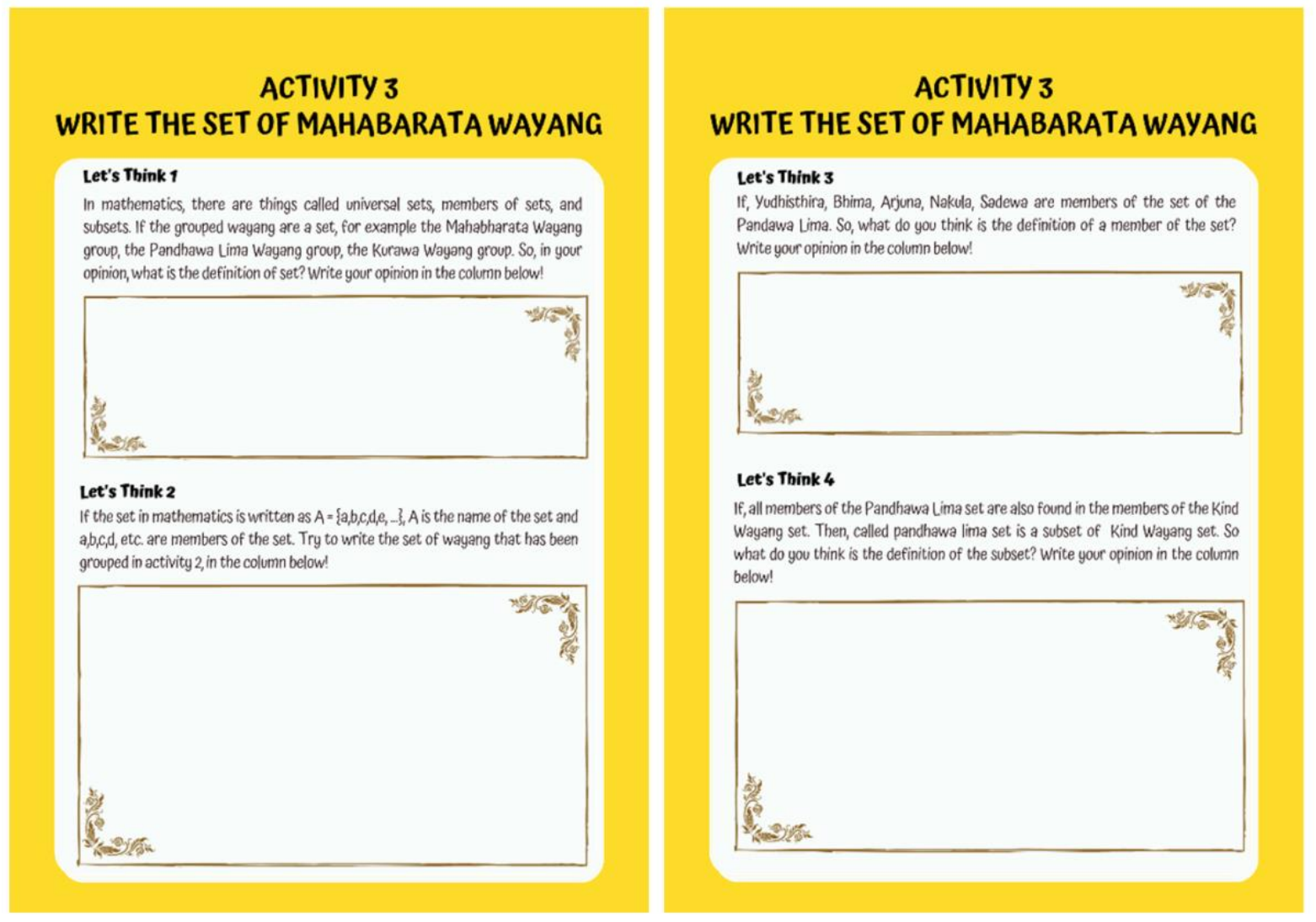

Figure 5. Student define set, members of set and subset 
Then, students define subsets when it is known that all the members of the five wayang pandhawa set are also in the wayang set with kind character. Then, given an example of writing subsets and how to describe them in the form of a Venn diagram. Students then find other subsets of the results of grouping wayang then written in a formal form and drawn in the form of a Venn diagram. Finally, students reflect on their learning experiences using the context of wayang and Mahabharata stories, especially learning experiences other than mathematical concepts. The illustaration can be seen in Figure 5 and Figure 6.

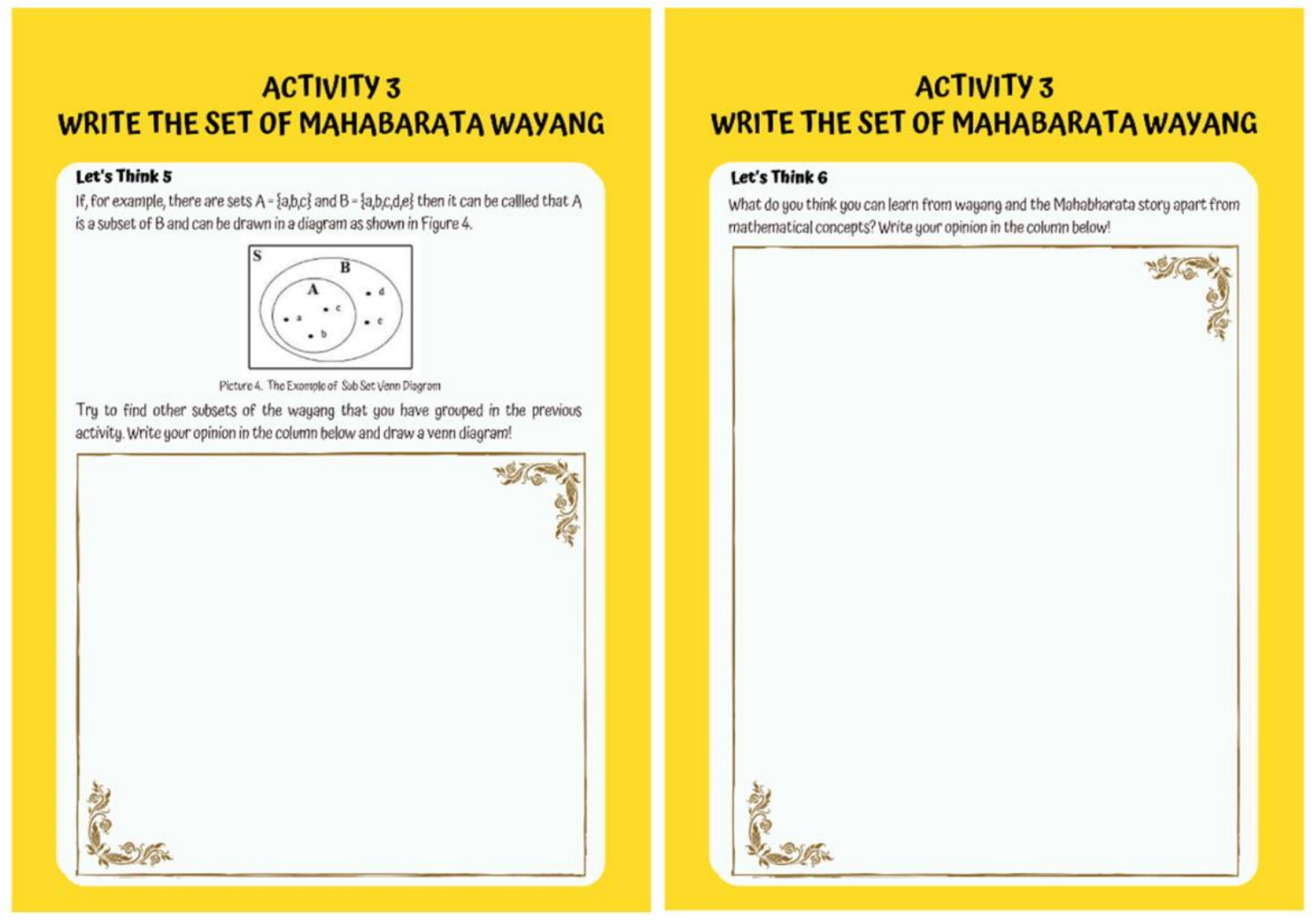

Figure 6. Student write set and subset in the formal form

The conjecture in the third activity consists of activities, predictions of student responses, and the responses that the teacher must give in response to the responses given by these students. The details can be seen in Table 4 .

Table 4. Conjecture of activity 3

\begin{tabular}{clll}
\hline No & Activity & \multicolumn{1}{c}{$\begin{array}{c}\text { Predictions } \\
\text { of student responses }\end{array}$} & \multicolumn{1}{c}{ Teacher's Responses } \\
\hline 1 & $\begin{array}{l}\text { Let's Think 1 } \\
\text { Students } \\
\text { define 'set' }\end{array}$ & $\begin{array}{l}\text { Students can define that a set as } \\
\text { a clearly defined collection of } \\
\text { objects, in their own language } \\
\text { Students have not been able to } \\
\text { define a set }\end{array}$ & $\begin{array}{l}\text { The teacher gives a verbal appreciation } \\
\text { for students }\end{array}$ \\
& $\begin{array}{l}\text { The teacher explores students' difficulties } \\
\text { which cause students not to be able to } \\
\text { define sets. Then the teacher ignites the } \\
\text { creativity of students' thinking by } \\
\text { inviting students to reflect on the } \\
\text { activities that have been done previously. }\end{array}$ \\
& & & \\
& &
\end{tabular}




\begin{tabular}{|c|c|c|}
\hline No & Activity & $\begin{array}{c}\text { Predictions } \\
\text { of student responses }\end{array}$ \\
\hline \multirow[t]{2}{*}{2} & $\begin{array}{l}\text { Let's Think } 2 \\
\text { Students }\end{array}$ & $\begin{array}{l}\text { Students can write sets in } \\
\text { formal form }\end{array}$ \\
\hline & $\begin{array}{l}\text { write the set- } \\
\text { in formal } \\
\text { form }\end{array}$ & $\begin{array}{l}\text { Students have not been able to } \\
\text { write sets in formal form }\end{array}$ \\
\hline
\end{tabular}

\section{Teacher's Responses}

The teacher gives a verbal appreciation for students

The teacher explores students' difficulties which cause students to not be able to write sets in formal form. Then the teacher ignites the critical and creativity of students' thinking by giving examples, and then students are asked to try themselves in writing the "set" in formal form.
$3 \quad$ Let's Think 3 Students can define that a Students define 'set members' member of a set as an object that is clearly defined, in their language

Students have not been able to define the members of the set
The teacher gives a verbal appreciation for students

The teacher explores students' difficulties that cause students not to be able to define members. Then the teacher ignites the critical and creativity of students' thinking by inviting students to reflect on the activities that have been done previously.
$4 \quad$ Let's Think 4 Students can define that a Students define "subsets" subset is a set whose members include members of other sets, with their language

Students have not been able to define subsets
The teacher gives a verbal appreciation for students

The teacher explores students' difficulties that cause students not to be able to define subsets. Then the teacher ignites the critical and creativity of students' thinking by inviting students to reflect on the activities that have been done previously.

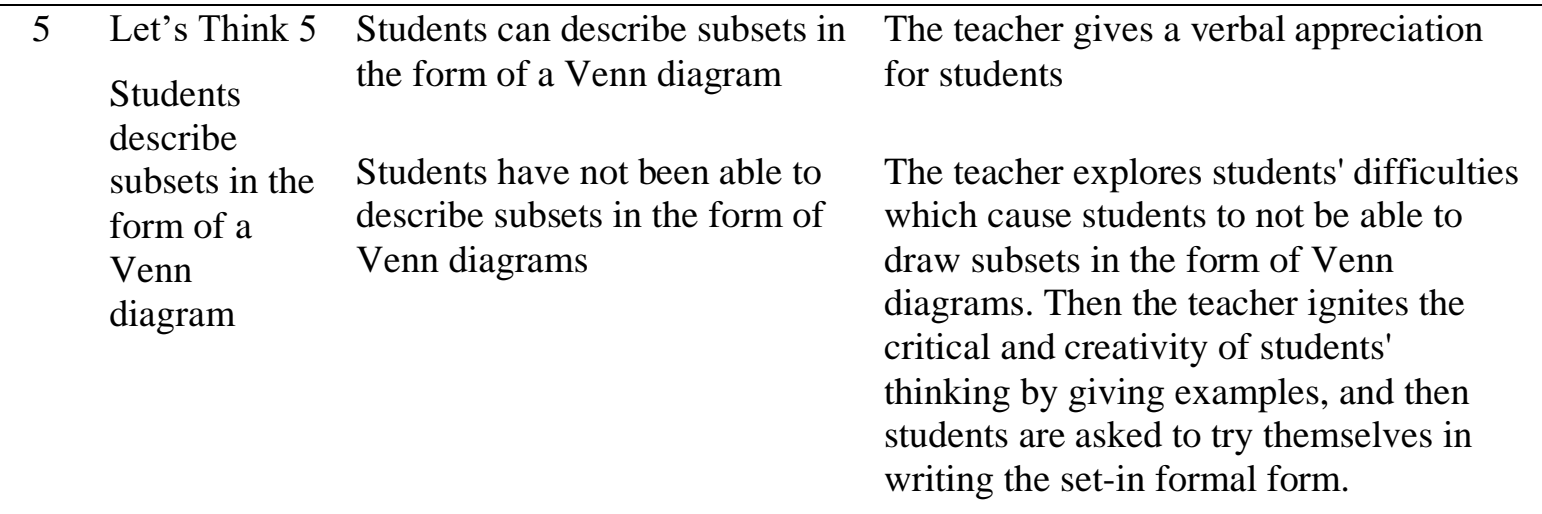




\begin{tabular}{clll}
\hline No & \multicolumn{1}{c}{ Activity } & \multicolumn{1}{c}{$\begin{array}{c}\text { Predictions } \\
\text { of student responses }\end{array}$} & \multicolumn{1}{c}{ Teacher's Responses } \\
\hline 6 & $\begin{array}{l}\text { Let's Think } 6 \\
\text { Students } \\
\text { explain } \\
\text { learning } \\
\text { experiences } \\
\text { obtained } \\
\text { from the } \\
\text { context of } \\
\text { wayang and }\end{array}$ & $\begin{array}{l}\text { Students can explain the social, } \\
\text { moral, or cultural values } \\
\text { contained in the wayang and } \\
\text { Mahabharata stories according } \\
\text { to their learning experience }\end{array}$ & $\begin{array}{l}\text { The teacher gives a verbal appreciation } \\
\text { for students }\end{array}$ \\
$\begin{array}{l}\text { Mahabharata } \\
\text { stories in } \\
\text { addition to } \\
\text { mathematical } \\
\text { concepts }\end{array}$ & $\begin{array}{l}\text { learning experiences other than } \\
\text { mathematical concepts, }\end{array}$ & $\begin{array}{l}\text { The teacher triggers students' critical and } \\
\text { creative thinking by giving examples. } \\
\text { Then students are asked to try their own } \\
\text { writing the set-in formal form. }\end{array}$ \\
\hline
\end{tabular}

\subsection{Discussion}

The learning design of this set uses an ethnomathematics context, namely Wayang and Mahabharata stories and the Realistics Mathematics Education (RME) approach. The context of the Wayang and the Mahabharata story was used in the design of this study because the context is close to Javanese culture, which is the culture of students, and also close to students' daily lives (Risdiyanti \& Prahmana, 2020a; D'Ambrosio, 2016). Furthermore, in some performances, such as at celebrations or government cultural events, Wayang and Mahabharata stories are often presented to entertain and educate the public (Lim, 2017; Sabunga et al., 2014). Seeing the problems in mathematics education where mathematics lessons are often considered a frightening specter and many students do not understand mathematical concepts because, in schools, they tend to be taught practical formulas without being explained in detail about the concept of sets and their use in everyday life. In comparison, mathematics is a human activity and must be related to culture and human daily live (Freudenthal, 2016). Therefore, cultural contexts such as wayang and Mahabharata stories are urgent to use in the learning process (Risdiyanti \& Prahmana, 2020b).

The RME approach is also effectively used as an approach in this design because RME has the characteristics of using a real context as a starting point in learning (Hadi, 2017; Prahmana et al., 2020). In addition, RME effectively encourages students' activeness and creative thinking skills because RME has characteristics, namely, learning is carried out with the student center or more active students. The teacher is only a facilitator and can bring up student thinking strategies where the strategy arises from critical thinking skills and creative students (Hadi, 2017; Gravemeijer, 1994; Sembiring, Hadi, \& Dolk, 2008). The activity in the set learning design using the context of Wayang and the Mahabharata story begins with students watching an animation of a wayang show with the Mahabharata story masterminded by Ki Seno. This activity is carried out based on the learning activities using the RME approach (Hadi, 2017; Prahmana, Zulkardi, \& Hartono, 2012; Sembiring et al., 2008). The first activity starts from the mode for the activity to introduce context in an abstract form, namely by how students watching the Mahabharata wayang then identify all the wayang characters in the story. This activity still uses the concrete form of this context. In addition to introducing context, students are asked to create a universal set through an 
actual context in this first activity, namely Wayang. Then enter the second activity, namely connecting or "mode for," where students classify the Wayangs based on their characters and based on their groups. After that, they compile the results of the classification on the wayang colors. Finally, the formal knowledge activity defines the universal set, members of the set, and subsets and can write it down formally. In this last activity, students could not use the context of the Wayang and the Mahabharata story again. When students have been able to write sets in standard form and are separated from context, it means that abstracting process of the concept of the set is successful (Hadi, 2017; Gravemeijer, 1994). The details can be seen from the iceberg illustration in Figure 7.

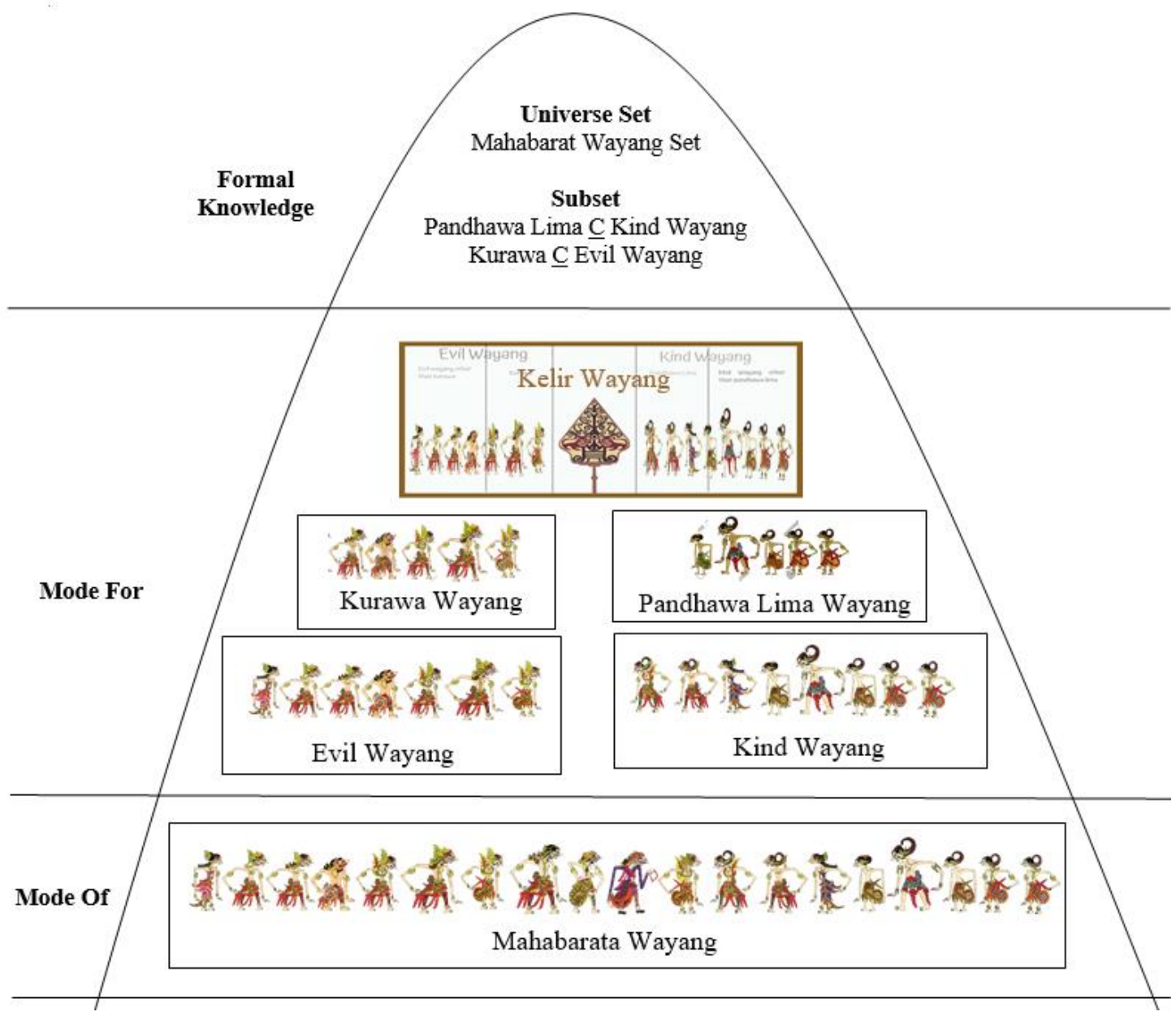

Figure 7. The iceberg of learning design of set using Wayang and Mahabharata story

The trajectory of the set learning design using Wayang and Mahabharata stories, as can be seen in the iceberg in Figure 7, are adjusted to the student learning flow contained in the mathematics learning curriculum made by the Indonesian Ministry of Education and Culture as well as the sequence of achievement of the competency standards included in the education curriculum in Indonesia (As'ari et al., 2017). The curriculum states that students understand the concept of the universal set, then set members, then subsets and write them informal form. In addition, some of the questions regarding activity three are adjusted to indicators of critical thinking skills, namely the ability to identify and justify concepts or the ability to provide mastery of ideas, the ability to generalize, the ability to analyze algorithms (Hendriana, Rohaeti, \& Sumarmo, 2017; Joyner \& Reys, 2000; Komariyah \& Laili, 2018). In addition, it is also adjusted to indicators of creative ability, namely fluency, flexibility, 
originality, and elaboration (Amidi \& Zahid, 2017; Hendriana et al., 2017; Joyner \& Reys, 2000).

This research has an additional reference in mathematics education to complement previous studies using the ethnomathematical context and RME approach in learning mathematics. For example, the story of the Wayang Barathayudha War and the Uno Stacko to learn number patterns (Risdiyanti \& Prahmana, 2020b), traditional Indonesian games in learning number operations (Prahmana et al., 2012), playing one house in learning number operations (Nasrullah \& Zulkardi, 2011), Patok Lele in measuring learning (Wijaya, 2008), the traditional Indonesian game Kubuk Manuk as a stimulated starting point to understand the knowledge of social arithmetic concepts (Risdayanti et al., 2019), and the Gasing game in measuring learning time (Jaelani, Putri, \& Hartono, 2013), and several mathematical activities in estimating, measuring, and making patterns using Sundanese culture (Muhtadi et al., 2017). Therefore, this study takes the role of adding context studies to be used as a starting point for learning mathematics.

\section{CONCLUSION}

The local contexts such as culture can use to understand the concept of sets. This study succeeded in designing the learning trajectory of the set using the RME approach with the context of Wayang and Mahabharata stories. The learning trajectory consists of three activities, namely watching the Mahabarata Wayang stories by Ki Seno, helping Ki Seno compose the Mahabarata Wayang on Kelir Screen, and writing the set of Mahabharata Wayang. This design allows students to rediscover the concept of sets from real and abstract contexts. It will make students understand mathematical concepts easily because it is fun for them, and most importantly, culture relates to activities in their daily lives. This research can play a role in developing the learning trajectory of the set using Wayang and Mahabharata stories as local learning contexts. It is also a basis to implement it in teaching experiments and analyze the result using retrospective analysis to construct the local instructional theory on set for further research.

\section{ACKNOWLEDGEMENTS}

The authors wish to express their gratitude to the Institute of Research and Community Services, Universitas Ahmad Dahlan, for supporting and funding this research through the Penelitian Tesis Magister (PTM) grant under contract number PTM201/SP3/LPPM-UAD/VI/2021. Additionally, the researcher wishes to express gratitude to the Master Program in Mathematics Education at Universitas Ahmad Dahlan for providing the researcher with the opportunity and resources necessary to complete this research.

\section{REFERENCES}

Alangui, W. V. (2010). Stone walls and water flows: Interrogating cultural practice and mathematics. Doctoral Dissertation. Auckland: University of Auckland.

Amidi, A., \& Zahid, M. Z. (2017). Membangun Kemampuan Berpikir Kreatif Matematis Dengan Model Pembelajaran Berbasis Masalah Berbantuan E-Learning. In PRISMA, Prosiding Seminar Nasional Matematika(pp. 586-594). Universitas Negeri Semarang. 
As'ari, A. R., Tohir, M., Valentino, E., Imron, Z., \& Taufiq, I. (2017). Buku guru matematika kelas VII SMP/MTs kurikulum 2013. Jakarta: Pusat Kurikulum dan Perbukuan, Balitbang, Kemendikbud.

D'Ambrosio, U. (1985). Ethnomathematics and its place in the history and pedagogy of mathematics. For the learning of Mathematics, 5(1), 44-48.

D'Ambrosio, U. (2007). Ethnomathematics: perspectives. North American Study Group on Ethnomathematics News, 2(1), 2-3.

D'Ambrosio, U. (2016). An overview of the history of Ethnomathematics. In M. Rosa, U. D’Ambrosio, D. C. Orey, L. Shirley, W. V. Alangui, P. Palhares, \& M. E. Gavarrete (Ed.). Current and Future Perspectives of Ethnomathematics as A Program (pp. 510). Cham: Springer. https://doi.org/10.1007/978-3-319-30120-4_2

Dwidarti, U., Mampouw, H. L., \& Setyadi, D. (2019). Analisis kesulitan siswa dalam menyelesaikan soal cerita pada materi himpunan. Jurnal Cendekia: Jurnal Pendidikan Matematika, 3(2), 315-322. https://doi.org/10.31004/cendekia.v3i2.110

Ernest, P., Skovsmose, O., Van Bendegem, J. P., Bicudo, M., Miarka, R., Kvasz, L., \& Moeller, R. (2016). The philosophy of mathematics education. Cham: Springer Nature. https://doi.org/10.1007/978-3-319-40569-8

Freudenthal, H. (2006). Revisiting mathematics education: China lectures (Vol. 9). Cham: Springer Science \& Business Media. https://doi.org/10.1007/0-306-47202-3

Gravemeijer, K. P. E. (1994). Developing realistic mathematics education. Utrecht: Faculty of Sciences, Freudenthal Institute.

Gravemeijer, K., \& Cobb, P. (2006). Design research from a learning design perspective. In Jvd. Akker, K. Gravemeijer, S. Mckenney, \& N. Nieveen (Ed.). Educational Design Research (pp. 17-51). London: Routledge Taylor and Francis Group. https://doi.org/10.4324/9780203088364

Hadi, S. (2017). Pendidikan matematika realistik (Teori, pengembangan dan implementasinya). Jakarta: PT Raja Grafindo Persada.

Hendriana, H., Rohaeti, E. E., \& Sumarmo, U. (2017). Hard skill dan soft skills matematik siswa. Bandung: Refika Aditama.

Jaelani, A., Putri, R. I. I., \& Hartono, Y. (2013). Students' strategies of measuring time using traditional Gasing game in third grade of primary school. Journal on Mathematics Education, 4(1), 29-40. https://doi.org/10.22342/jme.4.1.560.29-40

Joseph, G. G. (2010). The crest of the peacock: Non-European roots of mathematics. New Jersey: Princeton University Press. https://doi.org/10.1515/9781400836369

Joyner, J., \& Reys, B. (2000). Principles and standards for school mathematics: What's in it for you? Teaching children mathematics, 7(1), 26-29. https://doi.org/10.5951/TCM.7.1.0026

Kasim, S. (2018). Wayang dalam kajian ontologo, epistimologi dan aksiologi sebagai landasan filsafat ilmu. Jurnal Sangkareang Mataram, 4(1), 47-50.

Komariyah, S., \& Laili, A. F. N. (2018). Pengaruh kemampuan berpikir kritis terhadap hasil belajar matematika. JP3M (Jurnal Penelitian Pendidikan dan Pengajaran Matematika), 4(2), 53-58. 
Lim, Y. S. (2017). Wayang kulit and its influence on modern entertainment. In The Asian Conference on Media, Communication \& Film 2017 Official Conference Proceedings (pp. 111-124). The International Academic Forum.

Maryati, M., \& Prahmana, R. C. I. (2020). Designing learning rotation using the context of bamboo woven motif. Prima: Jurnal Pendidikan Matematika,4(2), 100-108. https://doi.org/10.31000/prima.v4i2.2600

Meirisa, A., Rifandi, R., \& Masniladevi, M. (2018). Pengaruh pendekatan pendidikan matematika realistik indonesia (PMRI) terhadap keterampilan berpikir kritis siswa SD. Jurnal Gantang, 3(2), 127-134. https://doi.org/10.31629/jg.v3i2.508

Muhtadi, D., Sukirwan, S., Warsito, W., \& Prahmana, R. C. I. (2017). Sundanese Ethnomathematics: mathematical activities in estimating, measuring, and making patterns. Journal on Mathematics Education, 8(2), 185-198. https://doi.org/10.22342/jme.8.2.4055.185-198

Nasrullah, N., \& Zulkardi, Z. (2011). Building counting by traditional game: A mathematics program for young children. Journal on Mathematics Education, 2(1), 41-54. https://doi.org/10.22342/jme.2.1.781.41-54

Novrika, D., Putri, R. I. I., \& Hartono, Y. (2016). Desain pembelajaran materi refleksi menggunakan motif kain Batik untuk siswa kelas VII. In Prosiding Seminar Nasional Matematika dan Pendidikan Matematika. Universitas Negeri Sebelas Maret.

Nursyahidah, F., Saputro, B. A., Albab, I. U., \& Aisyah, F. (2020). Pengembangan learning trajectory based instruction materi kerucut menggunakan konteks megono gunungan. Mosharafa: Jurnal Pendidikan Matematika, 9(1), 47-58.

Nurtasari, A. R., Jamiah, Y., \& Suratman, D. (2017). Miskonsepsi Siswa pada Materi Himpunan di Kelas VII SMP Santa Monika Kubu Raya. Jurnal Pendidikan dan Pembelajaran Khatulistiwa, 6(2), 1-10.

Plomp, T. (2013). Educational Design Research: An Introduction. In T. Plomp \& N. Nieveen (Ed.). Educational Design Research (pp. 10-51). Enschede: Netherlands Institute for Curriculum Development (SLO).

Prahmana, R. C. I. (2017). Design Research (Teori dan Implementasinya: Suatu Pengantar). Depok : Rajawali Pers.

Prahmana, R. C. I., Sagita, L., Hidayat, W., \& Utami, N. W. (2020). Two decades of realistic mathematics education research in Indonesia: A survey. Infinity Journal, 9(2), 223246. https://doi.org/10.22460/infinity.v9i2.p223-246

Prahmana, R. C. I., Yunianto, W., Rosa, M., \& Orey, D. C. (2021). Ethnomathematics: Pranatamangsa system and the birth-death ceremonial in Yogyakarta. Journal on Mathematics Education, 12(1), 93-112. http://doi.org/10.22342/jme.12.1.11745.93112

Prahmana, R. C. I., Zulkardi, Z., \& Hartono, Y. (2012). Learning multiplication using Indonesian traditional game in third grade. Journal on Mathematics Education, 3(2), 115-132. https://doi.org/10.22342/jme.3.2.1931.115-132

Putra, R. Y., Wijayanto, Z., \& Widodo, S. A. (2020). Etnomatematika: Masjid Soko Tunggal dalam pembelajaran geometri 2D. Jurnal Riset Pendidikan dan Inovasi 
Pembelajaran Matematika $\quad$ (JRPIPM), 4(1),

$10-22$. https://doi.org/10.26740/jrpipm.v4n1.p10-22

Rahmawati, Y. (2020). Pendekatan matematika realistik bernuansa Etnomatematika: Rumah gadang minangkabau pada materi teorema pythagoras. Jurnal Azimut, 3(SMAR), 2229.

Ratnasari, S., \& Setiawan, W. (2019). Analisis kesulitan belajar siswa pada materi himpunan. Journal on Education, 1(2), 473-479.

Risdiyanti, I., \& Prahmana, R. C. I. (2017). Ethnomathematics: Exploration in javanese culture. Journal of Physics: Conference Series, 943(1), 012032. https://doi.org/10.1088/1742-6596/943/1/012032

Risdiyanti, I., \& Prahmana, R. C. I. (2020a). Ethnomathematics (Teori dan Implementasinya: Suatu Pengantar). Yogyakarta: UAD Press.

Risdiyanti, I., \& Prahmana, R. C. I. (2020b). The learning trajectory of number pattern learning using Barathayudha war stories and Uno Stacko. Journal on Mathematics Education, 11(1), 157-166. https://doi.org/10.22342/jme.11.1.10225.157-166

Risdiyanti, I., Prahmana, R. C. I., \& Shahrill, M. (2019). The learning trajectory of social arithmetic using an Indonesian traditional game. Elementary Education Online, 18(4), 2094-2108. https://doi.org/10.17051/ilkonline.2019.639439

Rosa, M., \& Orey, D. C. (2016). State of the art in Ethnomathematics. In M. Rosa, U. D’Ambrosio, D. C. Orey, L. Shirley, W. V. Alangui, P. Palhares, \& M. E. Gavarrete (Ed.). Current and Future Perspectives of Ethnomathematics as A Program (pp. 1137). Cham: Springer. https://doi.org/10.1007/978-3-319-30120-4_3

Sabunga, B., Budimansyah, D., Sauri, S., \& Sanusi, A. (2014). Wayang Golek education values: Their potential to strengthen nationalism. International Journal of Education and Management Studies, 4(4), 287-292.

Sembiring, R. K., Hadi, S., \& Dolk, M. (2008). Reforming mathematics learning in

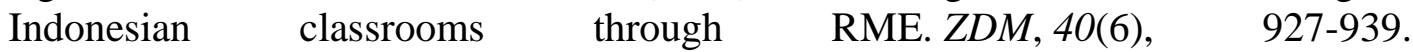
https://doi.org/10.1007/s11858-008-0125-9

Soedjadi, R. (2007). Inti dasar-dasar pendidikan matematika realistik Indonesia. Jurnal pendidikan matematika, 1(2), 1-10. https://doi.org/10.22342/jpm.1.2.807.

Utami, N. W., Sayuti, S. A., \& Jailani, J. (2019). Math and Mate in Javanese Primbon: Ethnomathematics study. Journal on Mathematics Education, 10(3), 341-356. https://doi.org/10.22342/jme.10.3.7611.341-356

Wijaya, A. (2008). Design research in mathematics education: Indonesian traditional games as means to support second graders' learning of linear measurement. Thesis. Utrecht: Utrecht University.

Zulkardi, Putri R. I. I., \& Wijaya A. (2020). Two decades of realistic mathematics education in Indonesia. In van den Heuvel-Panhuizen M. (Ed.). International Reflections on the Netherlands Didactics of Mathematics (pp. 325-340). ICME-13 Monographs. Cham: Springer. https://doi.org/10.1007/978-3-030-20223-1_18 